\title{
ZLODĚJI NEBO STRAŠIDLA: ČEHO SE BOJÍ ČESKÉ DĚTI?
}

\author{
Martin Brummer \& Hana Valentová
}

\begin{abstract}
Abstrakt
Výzkum se zabývá obsahem strachů u dětí v období mezi předškolním a středním školním věkem. V rámci longitudinální studie zjišt’uje intenzitu strachů z předem určených objektů, jejich proměnu v čase a rozdíly v závislosti na pohlaví. Výzkum je rozdělen na dvě fáze. V první fázi byly zjišt’ovány intenzity strachů u 40 dětí z mateřských škol a 39 dětí z druhých tříd základní školy. V druhé fázi bylo šetření replikováno u stejných skupin po dvouletém odstupu. Studie prezentuje základní informace o podobách strachu ve výše uvedeném období, předkládá data o proměnách reprezentací strachů $\mathrm{v}$ dětských představách, uvádí př́mé intenzity strachů z jednotlivých objektů a zasazuje je do vztahů se současnou tuzemskou i zahraniční literaturou.
\end{abstract}

Klíčová slova: strach, obavy, předškolní věk, mladší školní věk, střední školní věk

\section{THIEVES OR MONSTERS: WHAT ARE CZECH CHILDREN AFRAID OF?}

\begin{abstract}
The research is dealing with content of children's fear in the period between pre-school and middle school age. In the scope of a longitudinal study it focuses on the intensity offears from predetermined objects, their change in time and differences according to the gender. The research is divided in two phases. In the first phase, the intensity of fears was investigated within 40 children from nursery schools and 39 children from second classes of primary school. In the second phase, the investigation was replicated in the same groups after two years. The study presents basic information about the forms of fear in the above-mentioned period, presents data about changes in the representation of fears in the child's mind, mentions direct intensities of fears from the individual objects and sets them into relations between current domestic and foreign literature.
\end{abstract}

Keywords: fear, worries, pre-school age, primary school age, middle school age

Došlo: 22. 4. 2018

Schváleno: 4. 9. 2019 


\section{Úvod}

Oblast obsahů dětských strachů je jednou z obšírně probádaných oblastí dětské psychologie (Gullone, 2000). Strach je přímo spojený s lidským prožíáním a je neoddělitelnou částí lidské psychiky. $\mathrm{V}$ předmětu psychologie bývá zkoumán ze dvou různých úhlů pohledů podle formy, ve které se vyskytuje. Zatímco v oblasti psychopatologie je důraz kladen na patologické obdoby emočního prožívání (typickým prŕkladem jsou fobie), jeho obvyklá podoba je předmětem psychologie obecné či vývojové. Předkládaná práce se věnuje druhému typu strachu - jeho obvyklé formě bez abnormálních obsahů či výrazně zvýšené intenzity. Za obvyklé typy strachu lze u dětí pokládat takové, které ve své vyšší intenzitě netrvají u jedince déle než 2 roky (Graziano et al., 1979).

Předtím, než přistoupíme k podrobnější specifikaci dětských strachů, je nutné alespoň parciálně definovat podstatu strachu jako emoce. Strach patří mezi primární emoce, jehož funkcí je aktivizovat tělo a připravit je na střet v předtuše nebezpečné situace. Strach tak lze definovat jako „normální reakci na skutečné ohrožení, která zahrnuje nejméně tři responsivní systémy: a) zjevnou behaviorální reakci, b) skryté, subjektivní pocity a myšlenky a c) fyziologickou aktivitu“ (Nakonečný, 2012, s. 334).

Uvedenou reakci popisuje blíže Stuchlíková (2007, s. 145): „Strach bývá definován jako emocionální stav v prŕítomnosti nebo při očekávání nějakého nebezpečného, škodlivého nebo ohrožujícího podnětu, subjektivní prožitek extrémního zneklidnění, touha uniknout nebo podnět zneškodnit útokem, provázaná řadou reakcí sympatického NS [nervového systému]“. Obdobné definice uvádí také další autoři (Ekman, 2015; Graziano, 1979; Izard, 1991). Ústředním bodem strachu je jeho předmětnost. Existence předmětnosti odlišuje strach od úzkosti, kterou lze nazvat „,sesterskou“ emocí strachu. Strach musí být zaměřen na určitý jev, jakkoli nejasně definovaný. Pokud v proživání člověka danou zaměřenost nenalézáme, je nutné prožitek označit za úzkostný stav (pro podrobnější popis vztahů úzkosti a strachu viz Graziano et al., 1979; Hart \& Bossert, 1994; prŕípadně Ekman, 2015; Stuchlíková, 2007; Tillich, 2004).

Výzkum dětských strachů je obvykle zaměřen na deskripci obsahu strachů; je tedy zjišt'ováno, čeho konkrétně se děti v určitém věku bojí. Výzkumy nabírají nejčastěji podobu přímého dotazování dětí na předmět jejich strachů, přičemž se jedná o metodu využívanou již od konce 19. století (Gullone, 2000), jejíž výsledky jsou dobře zdokumentované (Bauer, 1976; Carroll \& Ryan-Wenger, 1999; Derevensky, 1974; Gullone, 2000; Lahikainen et al., 2003; Lentz, 1985; Michalčáková, 2007). Pro následné doplnění palety dětských strachů o jejich aktuálnost a intenzitu v proživání se využívá metod škálování k měření velikostí strachů z předkládaných vyobrazených či vyřčených podnětů (Hart \& Bossert, 1994; Lahikainen et al., 2003; Sayfan \& Lagattuta, 2009) či speciálních dotazníků (Gullone \& King, 1997; Michalčáková, 2007; Muris et al., 1997a).

Specifickým dotazníkem pro měření strachů je FSSC (Fear Survey Schedule for Children) a jeho revize (Scherer \& Nakamura, 1968; Ollendick, 1983; Gullone \& King, 1992; Jones \& Borgers, 1988). FSSC je jedním $\mathrm{z}$ nejčastěji používaných dotazníků $\mathrm{k}$ měření intenzit strachů pro svou snadnou administraci a velký počet měřitelných položek, které umožňují snadnou kvantifikaci a zobecnění. V českém prostředí využívá český překlad dotazníku ve svých pracích Stuchlíková (2007; 2010).

Využitím výše uvedených metod je $\mathrm{v}$ zahraniční literatuře $\mathrm{k}$ dispozici poměrně komplexní obraz o podobách a intenzitách strachů u dětí a to jak vzhledem k rostoucímu věku (Burnham \& Gullone, 1996; Carrol \& RyanWenger, 1999; Derevensky, 1974; Gullone, 2000; Gullone \& King, 1993; Hodková, 2013; Lentz, 1985; Neff \& Dale, 1996), tak k určujícímu pohlaví (Burnham \& Gullone, 
1996; Carroll \& RyanWenger, 1999; Graziano, 1979; Gullone, 2000; Gullone \& King, 1993; Jones \& Borgers, 1988; Muris, 1997b; Sayfan \& Lagattuta, 2009) či vztahu k představám rodičů (Jones \& Borgers, 1988; Mahat \& Scoloveno, 2003; Neff \& Dale, 1996; Salcuni et al., 2015).

Naopak v českém prostředí je oblast dětských strachů i přes zdůrazňování jejího významu (Michalčáková, 2007) zdokumentována výrazně méně. V zorném poli výzkumů se zde objevují děti prepubescentního či staršího věku (Michalčáková, 2007; Michalčáková et al., 2010; 2013; Zábranská, 2006). Jakkoli je zmapován vývoj intenzit strachů (a do jisté míry i podob) u dětí ve starším věku, studie mapující česká specifika dětí předškolního či mladšího školního věku dosud chyběla. Předkládaný výzkum byl proto zaměřen na zjišt’ování strachů u dětí právě v tomto věkovém období. Výsledky jsou zasazeny do kontextu zahraničních i domácích výzkumů.

Z dosud realizovaných výzkumů se v současnosti pokládají za potvrzené níže uvedené trendy. Výsledky dotazníkových šetření prostřednictvím FSSC definují 5 hlavních skupin strachů. První skupinou je strach z nebezpečí (kam patří například strach z AIDS, přepadení, vrahů, ohně apod.). Tato skupina je obsahově nejširší a zároveň se k jejím obsahům obvykle vážou nejvyšší intenzity strachu. Následující skupiny jsou uvedeny sestupně podle intenzity strachu, které děti ve vztahu k jejich obsahu zažívají: strach z neznámého (např. být sám doma, tma, ztracení se v davu, mrtvoly nebo mít špatné sny), strach ze zvířat (krysy, pavouci, hadi), strach ze školy/lékařŭ (psát test, jít k lékaři, mít špatné známky, setkat se s cizím člověkem) a strach z neúspěchu/kritiky (být kritizován, být bez přátel, vypadat hloupě, účastnit se potyčky). U všech skupin strachů byl zaznamenán pokles uváděných intenzit s rostoucím věkem dětí (Burnham \& Gullone, 1997; Gullone, 2000; Gullone \& King, 1993).

Strachy dětí v předškolním věku se vážou především na konkrétní jevy a události, které se vztahují ke každodennímu prožívání dětí (Gullone, 2000). Příkladem může být strach ze ztráty rodičů nebo ze tmy (Lahikainen et al., 2003). Jako další typický strach je u dětí v předškolním věku uváděn strach ze zvířat, především z pavouků (Lahikainen et al., 2003; Muris et al., 1997a). Vysokých intenzit dosahují také strachy z nadpřirozených bytostí - strašidel, monster apod. Strachy ze strašidel podle zahraničních studií dosahují vzhledem k ostatním strachům nejvyšší intenzity v tomto období, v mladším školním věku jejich aktuálnost postupně klesá (Gullone, 2000; Lahikainen et al., 2003; Lentz, 1985; Muris et al., 2000). V menší míře se u předškolních dětí dále objevují strachy ze strašidelných filmů, zranění, př́rodních jevů, divných lidí, usínání, vlastního selhání (Gullone, 2000; Lahikainen et al., 2003).

Výzkumy, které se zaměřují na hledání konkrétních objektů strachů u dětí mladšího školního věku, uvádějí nejčastěji strachy z nebezpečí, zvířat, přírodních jevů, strašidel, úmrtí rodiče, pobytu sám doma, tmy, lékaře a injekcí, školy, ztráty rodičů či kamarádů, zastřelení, nočních můr a usínání, televize, divných lidí, malého zranění (Bauer, 1976; Carrol \& RyanWenger, 1999; Derevensky, 1974; Hodková, 2013; Lahikainen et al., 2003; Lentz, 1985; Mahat \& Scoloveno, 2003; Muris et al., 2000; Neff \& Dale, 1996). Ve starším školním věku začínají mizet strachy z nadpřirozených jevů a strašidel a tyto obsahy jsou nahrazovány strachy ze školy, prrípadně z reálných jevů (Derevensky, 1974; Michalčáková et al., 2013; Muris et al., 2000). Přechod obsahů na reálné jevy nastává dříve u dívek (okolo 10. roku) než u chlapců (14. rok; Gullone \& King, 1997).

Kromě rozdílů obsahů a intenzit vzhledem $\mathrm{k}$ věku jsou v oblasti zájmu výzkumů také jejich rozdíly mezi pohlavími. V jednoduchosti lze shrnout, že jak dotazníková šetření prostřednictvím FSSC (Burnham \& Gullone, 1996; Gullone, 2000; Gullone \& King, 1993; Michalčáková, 2007; 
Michalčáková et al., 2010), tak práce zaměřené na specifičtější výseče problematiky (Jones \& Borgers, 1988; Gullone \& King, 1997; Graziano, 1979; Lentz, 1985; Muris et al., 1997a; 2000) uvádějí bud' výrazněji vyšší intenzitu strachů u dívek než u chlapců, př́ípadně větší počet jimi uváděných ohrožujících podnětů. Práce zpochybňující dané výsledky představují výjimky (Carroll \& Ryan-Wenger, 1999).

Lze předpokládat, že výše uvedené trendy jsou manifestovány také v podmínkách českého prostředí. Můžeme očekávat snižující se intenzity strachů uváděné staršími dětmi, rovněž i přesun jejich obsahů (z abstraktních nehmotných strachů do oblasti hmotných, školních, lékařských apod.). Pravděpodobný je výskyt výraznějších intenzit strachů u dívek než u chlapců u všech věkových souborů. Práce si klade za cíl nejen zjistit strukturu strachů u dětí předškolního až středního školního věku, ale zároveň nastínit jeho vývoj v průběhu 2 let. Na základě výsledků lze následně odvozovat vývojové trendy vobsazích strachů, hledat důvody jejich vzniku a dávat je do souvislosti s následnými proměnami ve starším školním věku (Michalčáková et al., 2013; Volková \& Dušková, 2015).

\section{Výzkumný vzorek}

Výzkum probíhal ve dvou fázích s dvouletým odstupem. V první fázi byly měřeny intenzity strachů u předškolních dětí a dětí mladšího školního věku. V druhé fázi byl sběr dat u stejných skupin zopakován.

Výzkumný soubor čítal v prvním kole šetření 40 dětí předškolního věku (20 dívek, 20 chlapců, věkový rozptyl 3-6 let, $\mathrm{M}=4,95$ ) a 39 dětí mladšího školního věku (21 dívek, 18 chlapců, věkový rozptyl 7-9 let, $M=7,95)$ ze Středočeského kraje, okresu Praha-východ.

Po dvou letech byly vybrány stejné děti pro druhou část výzkumu. Z předchozího souboru 40 dětí předškolního věku se výzkumu opětovně účastnilo 33 subjektů (17 dívek, 16 chlapců, věkový rozptyl 5-8 let, $M=6,58)$. Z dřívějšího souboru 39 dětí mladšího školního věku se studie účastnilo 36 dětí (19 dívek, 17 chlapců, věkový rozptyl 9-11 let, $M=10,02$ ).

V následujícím textu bude skupina 40 dětí předškolního věku označována jako skupina $\mathbf{1 A}$ a její stejní zástupci po 2 letech jako skupina 2A. Skupina 39 subjektů mladšího školního věku bude označována jako skupina 1B a jejich zástupci po 2 letech jako skupina 2B. To znamená, že skupiny 1 se vztahují ke stavu prvního šetření, zatímco skupiny 2 k šetření po 2 letech.

Diagram znázorňující změnu názvu skupiny po 2 letech. Skupiny označené 1 reprezentují odpovědi subjektů z 1. kola výzkumu. Skupiny 2 jsou reprezentovány daty z 2 . kola výzkumu (tzn. po 2 letech).

1A (předškolní děti) ----> 2A (předškolní žáci po 2 letech, především žáci 1. a 2. tříd)

1B (žáci 2. tříd) ---> 2B (žáci 2. tříd po 2 letech, žáci 4. tříd) 
Všimněme si, že skupina předškolních dětí v 1 . kole šetření dosáhla ve 2 . šetření obdobné věkové hranice subjektů druhého souboru $\mathrm{v} 1$. kole. Tento fakt umožňuje níže podrobnější srovnání skupin. Celkově výzkumný soubor postihuje období od předškolního věku po střední školní věk.

Obdobně byly označeny třídy v závislosti na pohlaví. Soubor všech dívek první fáze výzkumu je níže označován 1dívky, soubor chlapců 1chlapci. Skupina všech dívek druhého kola výzkumu nese označení 2dívky, soubor všech chlapců 2 chlapci.

Skupina všech dětí prvního kola je označována $\mathbf{1 A B}$, skupina všech dětí druhého výzkumu $\mathbf{2 A B}$.

\section{Metoda výzkumu}

Cílem výzkumu bylo zjistit prožívané intenzity strachů dětí z konkrétních objektů či situací, které jim byly postupně předkládány vyobrazené na kartičkách. Získané údaje bylo možné porovnat vzhledem k věku a pohlaví respondentů. Děti zde tudíž neuváděly spontánně strachy, kterých se bojí (v rámci odpovědi na otázku: „Řekni mi, čeho se bojíš.“). Namísto toho jim byly přímo prezentovány situace či objekty často asociované s pocitem strachu. Ty byly dříve vybrány výzkumníky, a úkolem dětí bylo s využitím obrázkové škály uvést, jak silný strach by v dané situaci nejspíše prožívaly.

Výhodou uvedeného designu je, že na rozdíl od prostého bezprostředního uvádění strachů zde respondent musí navíc přesně určit předpokládanou velikost strachu. Díky tomu lze uvažovat nad strachy, které by subjekt jinak z jakýchkoli důvodů opominul (nízká aktuálnost v době vyšetření, nesmělost apod.). Výhodou oproti měření přes FSSC je zadávání přesných objektů, které nejsou, a rozdíl od uvedeného dotazníku, následně spojovány prostřednictvím faktorové analýzy do abstraktních shluků. Zadáváním konkrétních objektů, které jsou podpořeny vizuální reprezentací (viz níže), dostáváme nejpřesnější údaje o vědomě prožívaném strachu z nich.

Subjektům byly postupně předkládány jednotlivé kartičky s obrázkovými reprezentanty strachů s žádostí, aby uvedly, jak hodně by se dané věci bály. Před děti byla nejprve umístěna řada pěti nakreslených obličejů se schematicky vyobrazenými výrazy (viz přiloha 2). Každému subjektu bylo vysvětleno, že má před sebou obličeje pěti pánů a každý z nich se v různé míře bojí. Pět různých stavů u obličejů bylo dětem popsáno jako: „ pán se nebojí vůbec; bojí se trošičku; bojí se; bojí se hodně; bojí se velmi hodně“. Dítě mělo emoční stavy u jednotlivých obrázků zopakovat. Pokud toho nebylo schopno, byly obličeje znovu popsány a následně bylo dítě znovu instruováno k popsání obličejů. Uvedený způsob škálování prožívaných strachů využívají ve svém výzkumu rovněž Sayfanová a Lagattutová (2008), které se zabývají odlišnostmi ve vnímání strachů u dívek a chlapců.

Následně bylo subjektům vysvětleno, že jim budou prezentovány obrázky s různorodými situacemi či objekty. Byl jim zadán úkol, aby u každého obrázku uvedly, jak velký by z daného objektu pocit’ovaly strach. Velikost strachu měly uvést slovně (např. hodně, trošičku apod.) a následně ukázat na obličej, který by reprezentoval, jak by se $\mathrm{v}$ dané situaci tvářily. Jednotlivé tváře reprezentovaly hodnotu strachu od nejnižší (hodnota 0 , dítě se vůbec objektu nebojí) po nejvyšší (4, dítě je při kontaktu s objektem zcela vyděšené). Jako sběrná odpověd' byl hodnocen ukázaný obličej. V průměru všech odpovědí dětí v určité skupině tak objekt strachu reprezentovala hodnota v rozmezí 0 až 4. Využívání obrázků ke zvýšení konkretizace úkolů při výzkumu strachů u předškolních dětí je v zahraničních studiích využíván jak při rozhovorových šetřeních (Muris \& kol, 2000; 2009), tak při zjišs'ování intenzit strachů s využitím měřící škály (Sayfan \& Lagattuta, 2008). 
Vizualizace situací byly před subjekty předkládány v následujícím pořadí: nebezpečné zvíre, tma, ztracení se, pavouk pod postelí, oheñ, strašidlo, voda, ostrý předmět, lupič, strašidelný film, lékař, pobyt sám doma, bubák pod postelí, divný člověk, velká výška, zbraň, odpor budící zvíre (pro grafický příklad 4 karet viz příloha 2). V druhé fázi šetření byl zjišt'ován také strach z bouřky. Ukázky některých z prezentovaných obrázků lze nalézt $\mathrm{v}$ př́loze 2.

Strach ze zviŕat byl vybrán pro jeho předpokládaný velký vliv na dětské prožívání. Ve výzkumech o dětských straších se na strach ze zvířat zaměřuje velká pozornost; bývá obvykle jedním z nejčastějších a zároveň nejintenzivnějších dětských strachů (Derevensky, 1974; Lahikainen et al., 2003; Lentz, 1985; Muris et al., 1997a; 2000). Jako výrazný je uváděn především strach z pavouků (Muris et al., 1997a). Pro ověření strachu z pavouků byla v předkládané studii vytvořena speciální položka pavouk pod postelí. Kvůli výrazně obecnému pojmu zvíře, byla skupina rozdělena na nebezpečné zviŕe (např. žralok, had apod.) a odpor budicí zviŕre (broet al.uk, červ apod.). U předškolních dětí je často uváděn rovněž strach ze strašidel, jehož intenzita s rostoucím věkem obvykle klesá. Kvůli významnosti strachu ze strašidel bylo i zde využito dvou zobrazení situací obsahující strašidlo - strašidlo a konkretizovanější bubák pod postelí. Rovněž následující objekty byly vybrány pro jejich častý výskyt ve studiích věnujících se strachu u dětí: tma, ztracení se, lupič, strašidelný film, lékař, pobyt sám doma, divný člověk (Burnham \& Gullone, 1997; Derevensky, 1974; Lahikainen et al., 2003; Lentz, 1985; Muris et at., 1997a; 1997b; 2000).

Uvedené situace byly doplněny objekty ostrý nůž a pistol. Strach z těchto objektů děti uvádí zřídka (Burnham \& Gullone, 1997; Lahikainen et al., 2003), častěji bývá zkoumán strach ze zranění, tudíž důsledek použití zbraně (Muris et al., 1997a; 1997b); přidány do souboru byly pro možnost zjištění, do jaké míry vyvolávají u dětí strach samy objekty vyvolávající zranění. Nedostatečně zmapovány jsou rovněž strachy z ohně, vody či vysoké výšky, které bývají zahrnovány do skupiny přírodních nebezpečí (Carroll \& Ryan-Wenger, 1999; Derevensky, 1974; Muris et al., 2000) či strachu ze zranění (Burnham \& Gullone, 1997). Z uvedených objektů bývá dětmi zmiňován nejčastěji oheň. Pro možnost porovnání strachu z ohně s dalšími „environmentálními“ strachy byly zařazeny také zbylé dva objekty (voda, velká výška). V druhé fázi šetření byl zjišs’ován také strach z bouřky, který byl $\mathrm{v}$ rámci doprovodného dotazování v prvním kole zmiňován př́buznými jako další výrazný dětský strach.

Získaná data byla následně porovnána $\mathrm{v}$ závislosti na věku a pohlaví dětí. Vzájemně byly porovnány intenzity u následujících skupin: $1 \mathrm{~A}$ vs $1 \mathrm{~B}, 2 \mathrm{~A}$ vs $2 \mathrm{~B}$, 1dívky vs 1 chlapci, 2dívky vs 2 chlapci, $1 \mathrm{AB}$ vs $2 \mathrm{AB}$. Způsob vyhodnocování dat je uveden níže.

Sběr dat probíhal v případě předškolních dětí v místě mateřské školy, v místnostech oddělených od ostatních dětí posuvnou zástěnou, případně ve zcela prázdné místnosti. Sběr dat u dětí na základní škole se uskutečnil během vyučování. Žáci byli postupně vyvoláváni ze třídy na chodbu, kde byla připravena lavice, za kterou ohodnocovali jednotlivé obličeje.

V obou fázích šetření byly př́buzným dětí poskytnuty písemně základní informace o výzkumném záměru, jeho cílech a způsobu realizace šetření. V př́padě zájmu o další informace měli možnost kontaktovat realizátory výzkumu telefonicky nebo prostřednictvím e-mailu. Všichni příbuzní dětí zařazených do výzkumného šetření poskytli písemný souhlas s účastí dítěte ve výzkumu. V prvním kole šetření podali příbuzní dětí několik námětů pro rozšíření sady strachů. Na základě těchto připomínek byla v druhém kole výzkumu sada rozšířena o strach z bouřky. 
Sběr dat v prvním kole šetření proběhl v rozmezí dubna a května roku 2014. Druhé kolo se konalo mezi březnem a červnem 2016.

\section{Výsledky}

Získaná data byla analyzována prostřednictvím programu IBM SPSS Modeler 15. Cílem analýzy bylo zjistit, v kterých oblastech či u kterých objektů je nejvýraznější rozdíl v intenzitách strachů. Rozdíly byly porovnávány na základě věku a pohlaví. Pro porovnání intenzit mezi objekty v jednotlivých fázích výzkumu byl využit Mann-Whitneyův pořadový test. K vzájemnému porovnání dat získaných z obou fází výzkumu, tudíž ke zjištění změn intenzit strachů během dvou let, byl použit Willcoxonův neparametrický test. Opakujeme, že porovnány byly intenzity strachů mezi následujícími skupinami: $1 \mathrm{~A}$ vs $1 \mathrm{~B}, 2 \mathrm{~A}$ vs $2 \mathrm{~B}$, 1 chlapci vs 1 dívky, 2 chlapci vs 2 dívky, $1 \mathrm{AB}$ vs $2 \mathrm{AB}$.

Tabulky 1.1 až 1.5 níže zobrazují výsledky proběhlé analýzy. V př́loze 1 jsou v tabulkách 2.1 až 2.5 vypsány průměrné hodnoty intenzit strachů u jednotlivých skupin. Dále v nich jsou tučně zvýrazněny pětice nejintenzivnějších objektů a uvedeny kategorie, u kterých byl mezi skupinami zjištěn statisticky významný rozdíl $(\mathrm{p}<0.05)$. V př́loze 1 jsou rovněž zobrazeny grafy 1.1 až 1.3 , které graficky znázorňují průměrné hodnoty uváděných strachů u jednotlivých skupin, a grafy 2.1 až 2.2 , které ukazují proměny pětice nejintenzivnějších strachů u dětí.

Nyní přistoupíme $\mathrm{k}$ výsledkům prvního šetření porovnávajícího hodnoty u skupin 1A (předškolní věk) a 1B (mladší školní věk). Pětice nejintenzivnějších strachů u skupiny 1A jsou sestupně: nebezpečné zvíře, ztracení se, strašidlo, lupič a bubák pod postelí. U skupiny 1B jimi jsou sestupně: nebezpečné zvíře, ztracení se a lupič, zbraň, strašidlo. Statisticky významný rozdíl $(\mathrm{p}<0.05)$ byl zjištěn u kategorií: strašidlo, ostrý předmět, pobyt sám doma, bubák pod postelí. U všech uvedených kategorií byla zjištěna snížená hodnota u skupiny 1B (mladší školní věk).

Z výsledků je patrné, že objektem vyvolávající u dětí nejvyšší míru strachu jsou nebezpečná divoká zvířata. U dané kategorie byly zaznamenány výrazně zvýšené hodnoty, které se u starších dětí ve větší míře nezměnily. Mezi nejintenzivnější strachy patří také strach ze separace od rodičů (ztracení se), lupičů či u mladších dětí z nereálných objektů (strašidlo, bubák pod postelí). Je zajímavé, že průměrné hodnoty jsou u všech kategorií nižší u starších dětí s výjimkou kategorie lupič, jejíž průměrná hodnota se mírně zvýšila. Celkově můžeme hodnotit, že v období mezi předškolním a mladším školním věkem se intenzita strachů spíše snižuje a to především u fantazijních kategorií (strašidlo, bubák pod postelí) a kategorií souvisejících s každodenními činnostmi dítěte (pobyt sám doma, ostrý předmět).

Následuje porovnání daných skupin po replikaci sběru dat po dvou letech. Ve skupině 2A (mladší školní věk) spadá pod 5 nejvýše hodnocených kategorií následující: nebezpečné zvíře, zbraň, lupič, ztracení se, strašidlo. U skupiny 2B (střední školní věk) jimi jsou: nebezpečné zviřre, lupič, ztracení se, zbraň, strašidlo. Statisticky významné rozdíly $(\mathrm{p}<0.05)$ byly zaznamenány u kategorií ostrý předmět, sám doma, zbraň - všechny hodnoty byly nižší u skupiny $2 \mathrm{~B}$.

Z výsledků vyplývá, že nejstrašidelnější stimuly jsou s rostoucím věkem u dětí poměrně stabilní. Spadá do nich především strach ze zvířat, který je následován strachem ze ztracení se a z lupiče intenzity u daných kategorí jsou vysoké ve všech věkových okruzích. U dětí předškolního věku je príitomen výrazný strach ze strašidel a jiných nereálných bytostí. Daný strach se v mladším školním věku výrazně snižuje (jak u strašidla, tak u bubáka pod postelí). Pozici strašidel nahrazují reálnější, „hmatatelnějšsi'“ hrozby v podobě výše zmíněného lupiče či zbraně. Zbraň v dětech vzbuzuje největší 
strach v mladším školním věku, ve středním školním věku se strach z ní snižuje. Zaměříme-li se na hodnoty průměrů, můžeme opatrně konstatovat, že strachy vzhledem k věku konstantně klesají, avšak nevyrovnaně u jednotlivých kategorií. Nejvýrazněji se snižuje strach z méně nebezpečných objektů či ze situací, které se děti učí s rostoucím věkem ovládat (at' již v praktické či mentální pozici; ostrý předmět, pobyt sám doma, postupně také zbraň).

Přejdeme k zjištěným intenzitám strachů u dívek a chlapců z prvního šetření. Nejintenzivnější strachy u skupiny 1dívky reprezentují sestupně následující objekty: nebezpečné zvíře, lupič, zbraň, ztracení se, strašidlo. U skupiny 1chlapci jsou kategorie s nejvyšším průměrným strachem následující: nebezpečné zvíře, ztracení se, strašidlo, lupič, tma. Statisticky významný rozdíl mezi skupinami ( $\mathrm{p}<$ 0.05) byl zjištěn u kategorií nebezpečné zviŕre, pavouk pod postelí, ostrý předmět, lupič a zbraň. U všech z uvedených rozdílů byly nižší hodnoty uváděny chlapci.

Ze zjištěných intenzit můžeme usuzovat, že dívky uvádí při posuzování objektů vyšší míru strachu než chlapci. Tento rozdíl je patrný především u objektů nepřátelských postav (lupič, nebezpečné zvíře) či objektů, které tyto postavy mohou vlastnit a používat (ostrý předmět, zbraň). V prípadě nereálných objektů nejsou rozdíly natolik výrazné. Jak můžeme pozorovat ve skladbě objektů s nejvyššími intenzitami, je možné, že jsou u chlapců v předškolním a mladším školním věku aktuálnější strachy z nereálných objektů (strašidlo, tma), zatímco dívky se více obávají hmotných nepřátelských objektů (lupič, zbraň).

Po dvou letech se uváděné intenzity dívek a chlapců mírně změnily. Pětici kategorií s nejvyššími hodnotami u skupiny 2dívky tvoří sestupně: lupič, zbraň, nebezpečné zvíře, ztracení se, strašidlo. U souboru 2chlapci jimi jsou následující kategorie: nebezpečné zvíře, ztracení se, lupič, strašidlo a pak se stejnými intenzitami bubák pod postelí, divný člověk, zbraň. Statisticky významný rozdíl (p $<0.05)$ byl zjištěn u kategorií lupič, lékař, zbraň. Intenzity u kategorií lupič a zbraň byly vyšší u dívek, naopak hodnota u kategorie lékař byla zaznamenána vyšší u chlapců.

Jak můžeme vyčíst z uvedených průměrných hodnot, po dvou letech přetrvává stav, kdy chlapci uvádí nižší míry intenzit strachů než dívky. Snížení počtu statisticky významných rozdílů mezi skupinami (z nichž $v$ jednom prŕpadě byla vyšší intenzita nalezena u chlapců) naznačuje, že rozdíly mezi pohlavími nejsou natolik výrazné jako v mladším školním věku. Celkově se k sobě obě skupiny s rostoucím věkem v uváděných intenzitách spíše přibližují.

Složení pětice nejintenzivnějších strachů u starších dívek naznačuje přerod v reakcích na strašidelné objekty. Z čela objektů s nejvyššími hodnotami se zde stáhla kategorie nebezpečné zvíře. Její místo nahradily kategorie lupič a zbraň. U chlapců zůstávají pozice kategorií stabilnější a výrazněji se od své podoby před 2 roky neliší. Překvapivý je výskyt kategorie bubák pod postelí, která je v rámci umístění uváděných intenzit u chlapců na poměrně vysoké pozici. 
Tab. 1.1 Výsledky srovnání skupin A1 vs B 1 získané prostřednictvím Mann-Whitneyova pořadového testu

\begin{tabular}{|c|c|c|c|c|c|c|c|c|c|c|c|c|c|c|c|c|c|}
\hline & Neb. zviŕe & Tma & Ztracení se & Pavouk p. p. & Ohen̆ & Strašidlo & Voda & Ostrý p. & Lupič & Straš. film & Lékar̆ & Sám doma & Bubák p. p. & Divný čl. & Vel. výška & Zbran̆ & Odpor. zvî́re \\
\hline $\mathrm{Z}$ & $-1,435$ &,- 176 &,- 455 &,- 347 &,- 363 & $-2,046$ & \begin{tabular}{|l|}
-927 \\
\end{tabular} & $-2,719$ &,- 252 &,- 700 & $-1,918$ & $-2,218$ & $-3,296$ & $-1,012$ & $-1,074$ &,- 694 & $-1,569$ \\
\hline Asymp. Sig. (2-tailed) &, 151 &, 860 & ,649 &, 728 &, 717 &, 041 &, 354 &, 007 &, 801 & , 484 &, 055 &, 027 &, 001 &, 311 & ,283 & , 488 & 117 \\
\hline
\end{tabular}

Tab. 1.2 Výsledky srovnání skupin 1chlapci vs 1dívky získané prostřednictvím Mann-Whitneyova pořadového testu

\begin{tabular}{|c|c|c|c|c|c|c|c|c|c|c|c|c|c|c|c|c|c|}
\hline & Neb. zvíre & Tma & $\begin{array}{c}\text { Ztracení } \\
\text { se }\end{array}$ & Pavouk p. p. & Oheň & Stra šidlo & Voda & Ostrý p. & Lupič & Straš, film & Lékar̆ & Sám doma & Bubák p. p. & Divný čl. & Vel. výsksa & Zbran̆ & Odpor. zvî́re \\
\hline $\mathrm{z}$ & $-2,078$ &,- 524 &,- 895 & $-2,027$ & $-1,895$ &,- 381 &,- 716 & $-2,053$ & $-2,789$ & $-1,504$ &,- 203 & -867 & $-1,144$ & -647 & $-1,274$ & $-2,857$ &,- 464 \\
\hline Asymp. Sig. (2-tailed) &, 038 & 600 &, 371 &, 043 &, 058 &, 703 & 474 &, 040 &, 005 & 133 &, 839 & 386 &, 252 &, 518 & 203 &, 004 &, 643 \\
\hline
\end{tabular}

Tab. 1.3 Výsledky srovnání skupin 1A vs $1 \mathrm{~B}$ získané prostřednictvím Mann-Whitneyova pořadového testu

\begin{tabular}{|c|c|c|c|c|c|c|c|c|c|c|c|c|c|c|c|c|c|c|}
\hline & Neb. zvir̃e & Tma & Ztraceni se & Pavouk p. p. & Oheň & Strašidlo & Voda & Ostrý p. & Lupič & Straš. film & Lékař & Sám doma & Bubák p. p. & Divný čl. & Vel. výška & Zbran̆ & Odpor. zvíre & Bouřka \\
\hline $\mathrm{z}$ & $-1,639$ &,- 496 &,- 862 &,- 850 &,- 445 & $-1,692$ &,- 489 & $-3,751$ & $-1,220$ & $-1,208$ &,- 249 & $-3,024$ & $-1,005$ &,- 163 &,- 883 & $-2,294$ &,- 446 & $-1,474$ \\
\hline $\begin{array}{l}\text { Asymp. Sig. (2- } \\
\text { tailed) }\end{array}$ & , 101 &, 620 & ,389 & ,395 &, 656 &, 091 &, 625 &, 000 &, 222 & ,227 & ,803 &, 002 &, 315 &, 871 &, 377 &, 022 & ,655 & , 140 \\
\hline
\end{tabular}

Tab. 1.4 Výsledky srovnání skupin 2chlapci vs 2dívky získané prostřednictvím Mann-Whitneyova pořadového testu

\begin{tabular}{|c|c|c|c|c|c|c|c|c|c|c|c|c|c|c|c|c|c|c|}
\hline & Neb. zviře & Tma & Ztracení se & Pavouk p. p. & Ohen̆ & Strašidlo & Voda & Ostrý p. & Lupič & Straš. film & Lékař & Sám doma & Bubák p. p. & Divný čl. & Vel. výska & Zbrañ & Odpor. zvĩ̃e & Bouřka \\
\hline $\mathrm{z}$ &,- 424 &,- 671 & $-1,374$ & $-1,390$ &,- 655 &,- 769 & $-1,497$ & $-1,916$ & $-2,683$ &,- 905 & $-2,384$ &,- 288 &,- 832 &,- 558 &,- 765 & $\mid-3,376$ & $-1,550$ &,- 576 \\
\hline $\begin{array}{l}\text { Asymp. Sig. (2- } \\
\text { tailed) }\end{array}$ &, 672 &, 502 &, 169 &, 165 &, 512 &, 442 & ,134 &, 055 &, 007 &, 366 &, 017 &, 774 &, 405 &, 577 &, 445 &, 001 &, 121 &, 564 \\
\hline
\end{tabular}

Tab. 1.5 Výsledky srovnání skupin $1 \mathrm{AB}$ vs $2 \mathrm{AB}$ získané prostřednictvím Wilcoxonova neparametrického testu

\begin{tabular}{|c|c|c|c|c|c|c|c|c|c|c|c|c|c|c|c|c|c|}
\hline & Neb. zvir̃e & Tma & $\begin{array}{c}\text { Ztracení } \\
\text { se }\end{array}$ & Pavouk p. p. & Oheň & Strašidlo & Voda & Ostrý p. & Lupič & Straš. film & Lékař & Sám doma & Bubák p. p. & Divný čl. & Vel, výška & Zbraň & $\begin{array}{c}\text { Odpor. } \\
\text { zviŕre }\end{array}$ \\
\hline $\mathrm{z}$ & $-2,914(\mathrm{a})$ & $-3,446(\mathrm{a})$ & $-404(b)$ &,$- 087(\mathbf{a})$ &,$- 568(a)$ &,$- 136(a)$ & $-1,841(\mathrm{a})$ & $-1,332(\mathrm{a})$ &,$-- 205(\mathrm{~b}) \mid$ &,$- 075(b)$ & $-2,283(\mathrm{a})$ & $-1,995$ (a) &,$- 103(\mathrm{a})$ &,$- 505(\mathrm{a})$ &,$- 070(b)$ & $\mid-, 675(a)$ &,$- 365(a)$ \\
\hline Asymp. Sig. (2-tailed) &, 004 &, 001 &, 686 & ,931 &, 570 & 892 &, 066 &, 183 &, 838 & 940 &, 022 &, 046 & 918 & ,614 & 944 &, 500 &, 715 \\
\hline
\end{tabular}


Konečně se dostáváme k rozdílům intenzit u jednotlivých kategorií mezi skupinami všech dětí z prvního (1AB) a druhého (2AB) kola šetření. Pětice kategorií, u kterých byly v průměru zaznamenány nejvyšší uváděné hodnoty, jsou v prrípadě skupiny $1 \mathrm{AB}$ následující (řazeny sestupně): nebezpečné zvíře, ztracení se, lupič, strašidlo, zbraň. U skupiny $2 \mathrm{AB}$ jimi jsou: nebezpečné zvíře, lupič, ztracení se, zbraň, strašidlo. Statisticky významné rozdíly byly zjištěny u kategorií nebezpečné zvíře, tma, lékař, sám doma. U daných kategorií byla nižší hodnota zjištěna u skupiny $2 \mathrm{AB}$.

Rozdíly v první pětici strachů jsou nízké. Nejvyšší hodnoty dosahuje u obou skupin kategorie nebezpečné zviŕe. U skupiny $2 \mathrm{AB}$ byly vyšší hodnoty zjištěny u kategorií lupič a zbraň. Propadla se naopak kategorie strašidlo. V celkovém průměru uváděných intenzit se za dva roky nejvíce snížily hodnoty kategorií nebezpečné zvíře, tma, lékař, pobyt sám doma. Kromě uvedených kategorií není rozdíl mezi skupinami $1 \mathrm{AB}$ a $2 \mathrm{AB} v$ celkových průměrech výrazný.

\section{Diskuze}

Přistupme nejprve k obsahům strachů při porovnávání věkových skupin. Obsahy strachů, které na sebe vázaly největší intenzity, byly $\mathrm{v}$ př́padě předškolních dětí $\mathrm{z}$ velké části nereálné strašidlo, bubák pod postelí. Podle Derevenskyho (1974) lze také strach ze zvířat do určité míry pokládat za strach imaginární, když upozorňuje na zcela nepatrnou možnost, že by dítě mohlo (s výjimkou návštěvy zoologické zahrady, tudíž situace zcela kontrolovatelné) potkat nebezpečné zvíře, jako je lev, tygr apod. To potvrzuje Lentz (1985), který předpokládá, že strach ze zvířat v sobě u mladších dětí částečně materializuje jejich neurčité, generalizované strachy.

Naopak u starších dětí (mladší a střední školní věk) se obsahy strachů přesouvají do reálnější oblasti; strachy ze strašidel jsou postupně upozad'ovány. Jejich místo nejintenzivnějších strachů přebírají strachy z reálných a představitelných hrozeb - lupiče, případně zbraně. Předpoklad tendence k přesouvání obsahů strachů z nereálné sféry do oblasti přesněji zaměřených představ je v souladu s dřívějšími zjištěními (Bauer, 1976; Derevensky, 1974; Muris et al., 2000).

Manifestace nejvyššího strachu z nebezpečného zvířete u všech skupin subjektů (s výjimkou starších dívek) podporuje závěry Murise (2000), který poukazuje na výrazný vliv představ zvířat na oblast strachů u dětí mladšího i středního školního věku. Výsledky se naopak mohou zdát v rozporu se závěry Burnhama a Gullonové (1996), ve kterých strach ze zvírat zaujímal v celkové intenzitě třetí z celkem pěti vygenerovaných faktorů (za strachem ze smrti a nebezpečí a strachem z neznáma). Je třeba brát v úvahu, že položky strachů ze smrti byly v uvedené studii natolik generalizované, že by je bylo možné do jisté míry začlenit do strachu ze zvířat (což se projevuje ve výsledcích Burnhama a Gullonové například zařazením strachu ze žraloka pod strach $\mathrm{z}$ nebezpečí). Strach ze zvířat tak v předkládaném výzkumu v sobě zahrnuje jevy, jež byly u Burnhama a Gullonové explicitně pojmenovány (např. strach z vraždy, elektrických šoků apod.). Obdobného názoru, že strach ze zvířat v sobě (především u mladších dětí) zahrnuje strach ze zranění či smrti, je Muris a kol. (1997a). Vysoká intenzita byla u mladších i starších dětí zjištěna kromě skupiny nebezpečné zvíře rovněž u kategorie ztracení se. Obsah strachu ze ztracení se referuje prŕmmo k separační úzkosti u dětí a jeho stabilní podoba není překvapující. 
V rovině změn intenzit strachů mezi dětmi předškolního a mladšího školního věku poklesl výrazně strach ze strašidel, ostrého předmětu, pobytu sám doma a bubáka pod postelí. Potvrzuje se výše zmíněný pokles strachů z nereálných bytostí s rostoucím věkem dětí. Tento pokles není potvrzen rozdíly intenzit mezi dětmi mladšího školního a středního školního věku. Strach $\mathrm{z}$ nereálných objektů tedy klesá nejvíce $\mathrm{v}$ přechodu mezi předškolním a mladším školním věkem dítěte. Následný pokles intenzity $\mathrm{v}$ dalším období je již pouze mírný. To je v souladu s předpokladem Carrollové a Ryan-Wengerové (1999), že v oblasti strachů je pro mladší školní věk typický výrazný pokles strachu ze strašidel. Vrchol intenzity daného strachu je dle Bauera a Derevenského (2000) období šestého roku.

Pokles strachu z pobytu sám doma pravděpodobně souvisí s větší samostatností dětí, kdy si začínají navykat na obdobné situace. Intenzita daného strachu výrazně klesá rovněž v období mezi mladším a středním školním věkem. Podobně klesá intenzita strachu z ostrého předmětu - nástroj, který může způsobit zranění, je již pravděpodobně více chápán jako neutrální objekt, se kterým lze manipulovat než jako potencionální nebezpečí. Takové pojetí předmětů jako využitelných prostředků je rozvíjeno ve středním školním věku, kdy u dětí výrazně klesl strach ze zbraní. Lze předpokládat, že prŕíčina tohoto poklesu je stejná jako u ostrých předmětů - dítě začíná zbraň vnímat jako neutrální prostředek, jenž není sám o sobě nebezpečný.

Zvýšená soběstačnost dětí, kterou lze usuzovat z postupného snižování intenzit strachů, má své meze ve výše zmíněném strachu ze ztracení se. Zdá se, že se děti i ve středním školním věku dokáží vypořádat se zkouškami okolí pouze v př́padě, že se zkoušky odehrávají ve známém prostředí nebo pod dozorem rodičů či jiných osob poskytujících podporu.

V souhrnu výsledků je evidentní, že oblast strašidel a strach z nich je pro děti nejaktuálnější v období předškolního věku. $\mathrm{V}$ daném období strašidla pro děti představují pravděpodobně zástupný objekt generalizovanějších strachů a úzkostí. V mladším školním věku jejich vliv na dětské prožívání výrazněji klesá. Následný ústup strachu ze strašidel v mladším a středním školním věku je již spíše pozvolného charakteru, což odpovídá výsledkům Shraonové a Woolleyové (2004). Dále postupně v celém období od předškolního do mladšího školního věku klesá strach ze situací vyžadujících větší samostatnost dítěte - strach z pobytu sám doma, ostrého předmětu a u dětí středního školního věku strach ze zbraně.

V př́ípadě nejintenzivnějších strachů u mladších dívek a chlapců (předškolní věk a mladší školní věk) je pětice strachů u obou skupin obdobná. Obě skupiny se nejvíce bojí nebezpečných zvířat. U dívek následují strachy z lupiče či zbraně. Naopak u chlapců jsou výše postaveny strachy ze strašidel a tmy. To naznačuje, že dívky hodnotí vyšší intenzitou reálné strachy (ve smyslu teoreticky možných a ohrožujících), naopak chlapci přisuzují větší míru strachu objektům neznámým a nehmotným (strašidlo, tma).

Výraznější rozdíl v nejintenzivnějších straších je přítomen u starších dívek a chlapců (mladší a střední školní věk). U dívek byl poprvé nahrazen nejintenzivnější strach (z nebezpečného zvířete) jiným obsahem - lupičem. Na pozici druhého nejintenzivnějšího strachu vystoupal strach ze zbraně, naopak výrazněji se propadl strach ze strašidla. U chlapců přetrval na nejvyšší pozici strach z nebezpečných zviŕat. Vysokou pozici zabírá strach ze strašidel a mezi třemi nejintenzivnějšími strachy na páté pozici se u chlapců objevuje strach z bubáka pod postelí. Zdá se, že výše předpokládaná transgrese obsahu strachů z nereálných, neznámých a generalizo- 
vaných strachů na lépe definované a hmotné objekty se děje dříve a dokonaleji u dívek, zatímco u chlapců je přesun strachů na reálné objekty pozvolnější. Výsledky nepodporují předpoklad Michalčákové (2007) a Vymětala (2004) o vyšší intenzitě strachů z nadpřirozených bytostí u dívek. Naopak jsou naše výsledky v souladu s před-pokladem vysloveným a ověřeným Murisem (Muris et al. 1997b; 2000), že je téma strašidel pro chlapce dlouhodobě atraktivnější než pro dívky.

Výraznější rozdíly $\mathrm{v}$ intenzitách $\mathrm{u}$ mladších dívek a chlapců byly zjištěny $\mathrm{u}$ kategorií nebezpečné zvíře, pavouk pod postelí, ostrý předmět, lupič, zbraň. U všech z uvedených kategorií byla nižší intenzita zjištěna u chlapců. U starších dívek a chlapců se rozdíly v intenzitách objevily u kategorií lupič, lékař, zbraň. V př́ípadě lékaře byla větší průměrná intenzita naměřena u chlapců, zbylé dvě byly vyšší u dívek.

Vzhledem k vyššímu počtu výrazných rozdílů mezi pohlavími u mladších dětí a $\mathrm{k}$ tomu, že naprostá většina průměrů uváděných intenzit je u kategorií nižší u chlapců, lze tvrdit, že v mladším školním věku je prŕítomen výrazný rozdíl mezi chlapci a dívkami v uváděných intenzitách strachů. Tento rozdíl je v souladu s předchozími výzkumy (Gullone, 2000; Muris et al., 1997a, 1997b, 2000). Jednoduché zobecnění komplikují výsledky u starších dětí - zde se již s jistotou nedá tvrdit, že chlapci uvádějí v průměru nižší intenzity strachů. Obdobné výsledky prezentuje Michalčáková (2007), která zjistila rozdíl v intenzitách strachů mezi pohlavími v období okolo 11 let; okolo 13. roku již výraznější rozdíly nebyly zaznamenány. Výsledky zpochybňují tvrzení, že u dětí před 7. rokem jsou rozdíly ve velikostí strachů mezi dívkami a chlapci minimální (Lahikainen et al., 2003). Naopak se zdá, že se rozdíly s rostoucím věkem snižují.

Konečně v porovnávání celých souborů po dvou letech (předškolní věk a mladší školní věk vs mladší školní věk a střední školní věk) se skladba nejvýraznějších strachů výrazně nezměnila, pouze se mírně proměnilo jejich pořadí. V trojici nejintenzivnějších strachů setrvává v obou případech nebezpečné zvíře, ztracení se a lupič. V případě intenzit strachů výrazně klesly velikosti strachů z nebezpečného zvířete, tmy, lékaře a pobytu sám doma - tudíž především u strachů ze situací, se kterými mají možnost se častěji setkat v přímé zkušenosti. Ostatní typy strachů jsou v průměru takřka totožné.

\section{Závěr}

Změny v intenzitách a aktuálnosti strachů u dětí probíhají pozvolna a postupně. S rostoucím věkem setrvale klesá intenzita strachů u jednotlivých položek. Mezi předškolním a mladším školním věkem se snižuje především velikost strachů z nadpřirozených bytostí (strašidlo, bubák pod postelí), které byly $\mathrm{v}$ předškolním věku v popředí dětských strachů. Mezi mladším a středním školním věkem klesá v návaznosti na předchozí období strach z předmětů a situací, vyžadujících větší samostatnost (pobyt sám doma, ostrý předmět, částečně zbraň).

Mezi dívkami a chlapci byl největši rozdíl v intenzitách strachů zjištěn v předškolním a mladším školním věku. Dívky uváděly v průměru větší velikosti strachů, největší rozdíly se objevily u kategorií spojených s hrozbou fyzické konfrontace (nebezpečné zvíre, pavouk pod postelí, ostrý předmět, lupič, zbraň). Rozdíly v intenzitách mezi chlapci a dívkami 
v mladším a stř̌edním školním věku byly výrazněji nižší - chlapci dále uváděli nižší intenzity u lupiče a zbraně, vyšší u lékaře.

Skladba nejintenzivnějších strachů zůstávala u všech období podobná. S rostoucím věkem se postupně snižuje velikost strachů z nereálných bytostí (strašidla). Na jejich místě nejintenzivnějších strachů je nahrazují strachy z reálných hrozeb, které jsou sice nepravděpodobné, přesto představují riziko ohrožení života (především strach z lupiče). Tento trend se rychleji a výrazněji projevuje u dívek, zatímco chlapci setrvávají po delší čas v oblasti strachů ze strašidel.

Výsledky výzkumu nám umožňují nahlédnout do oblastí vývoje každodenních dětských strachů a jejich důležitosti; dávají částečný obraz o podobách a velikostech strachů u dívek a chlapců v rozmezí předškolního a středního školního věku. Zaplňuje se tak doposavad prázdné místo ve výzkumech strachů u českých dětí. Ty se zaměřovaly především na subjekty starší - žáky navštěvující druhý stupeň základní školy, případně školy střední. Současně studie upozorňuje na výrazný vliv strachů na prožívání dětí v běžném životě. $V$ dalších výzkumech strachů u dětí je trreba pojmout strachy $\mathrm{z}$ větší šíře a nabídnout k měření obsáhlejší paletu strachů - zajímavé by bylo zjistit především vývoj sociálních strachů z veřejného vystupování, strachů v oblasti školní docházky apod. Dosud v českém prostředí výrazně opomíjenou oblastí je rovněž pohled rodičů na strachy dětí. Zatímco zahraniční studie (Jones \& Borgers, 1988; Mahat \& Scoloveno, 2003) naznačují, že rodiče podceňují velikost dětských strachů, není tento předpoklad v českém prostředí potvrzen. K dalším výzkumům vybízí také teoreticky otevřené téma podmíněnosti rozdílných intenzit strachů pohlavím a vývoj této podmíněnosti od dětského věku po dospělost.

\section{Literatura}

Bauer, D. H. (1976). An explanatory study of developmental changes in children's fears. The Journal of Child Psychology and Psychiatry, 17, 69-74. https://doi.org/10.1111/j.14697610.1976.tb00375.x

Burnham, J. J., \& Gullone, E. (1997). The fear survey schedule for children-II: A psychometric investigation with American data. Behaviour Research and Therapy, 35(2), 165-173. https://doi.org/10.1016/S0005-7967(96)00089-7

Carroll, M., K., \& Ryan-Wenger, N. A. (1999). School-age children's fears, anxiety, and human figure drawings. Journal of Pediatric Health Care, 13, 24-31. https://doi.org/10.1016/S0891-5245(99)90097-4

Derevensky, J. (1974). What children fear. McGill Journal of Education, 9(1), 77-85. https://mje.mcgill.ca/article/view/6951

Ekman, P. (2015). Odhalené emoce. Brno: Jan Melvil Publishing.

Graziano, A. M., \& Degiovanni, I. S., \& Garcia, K. A. (1979). Behavioral treatment of children's fears: A review. Psychological Bulletin, 86(4), 804-830. https://doi.org/10.1037//0033-2909.86.4.804

Gullone, E. (2000). The development of normal fear: A century of research. Clinical Psychology Review, 20(4), 429-451. https://doi.org/10.1016/S0272-7358(99)00034-3 
Gullone, E., \& King, N. (1992). Psychometric evaluation of a revised fear survey schedule for children and adolescents. The Journal of Child Psychology and Psychiatry, 33(6), 987-998. https://doi.org/10.1111/j.1469-7610.1992.tb00920.x

Gullone, E., \& King, N. (1993). The fears in youth in the 1990s: Contemporary normative data. The Journal of Genetic Psychology, 154(2), 137-153.

https://doi.org/10.1080/00221325.1993.9914728

Gullone, E., \& King, N. (1997). Three-year follow-up of normal fear in children and adolescents aged 7 to 18 years. British Journal of Developmental Psychology, 15, 97-111. https://doi.org/10.1111/j.2044-835X.1997.tb00727.x

Hart, D., \& Bossert, E. (1994). Self-reported fears of hospitalized school aged children. Journal of Pediatric Noursing, 9(2), 83-90.

Hodková, K. (2013). Úzkost a strach u dětí mladšího školního věku z pohledu dítěte a rodiče. Bakalářská práce. Pedagogická fakulta Jihočeské univerzity. Dostupné z https://theses.cz/id/1vvdw6/

Izard, C., E. (1991). The Psychology of Emotions. New York: Springer Science \& Business Media.

Jones, E., \& Borgers, S. (1988). Parent perceptions of children's fear. Elementary School Guidance \& Counseling, 23(1), 10-15. https://www.jstor.org/stable/42868835

Lahikainen, A., R., Kirmanen, T., Kraav, I., \& Taimalu, M. (2003). Studying fears in young children: Two interview methods. Childhood, 10(1), 83-104.

https://doi.org/10.1177/0907568203010001005

Lentz, K. (1985). The expressed fears of young children. Child Psychiatry and Human Development, 16(1), 3-13.

Mahat, G., \& Scoloveno, M. A. (2003). Comparison of fears and coping strategies reported by nepalese school-age children and their parents. Journal of Pediatric Nursing. 18(5), 305-313. https://doi.org/10.1016/S0882-5963(03)00102-7

Michalčáková, R. (2007). Strachy v období rané adolescence. Brno: Společnost pro odbornou literaturu - Barrister \& Principal.

Michalčáková, R., Lacinová, L., Bouša, O., \& Kotková, M. (2010). Strachy a citová vazba k rodičům v období rané adolescence. E-psychologie. 4(1), 16-29. https://www.epsycholog.eu/pdf/michalcakova_etal.pdf

Michalčáková, R., Lacinová, L., Kyjonková, H., Bouša, O., \& Jelínek, M. (2013). Fears in Czech adolescents: A longitudinal study. Journal od Early Adolescence, 20(10), 1-19. https://doi.org/10.1177/0272431613485820

Muris, P., Merckelbach, H., \& Collaris, R. (1997a). Common childhood fears and their origins. Behaviour Research and Therapy, 35(10), 929-937. https://doi.org/10.1016/S00057967(97)00050-8

Muris, P., Merckelbach, H., Meesters, C., \& van Lier, P. (1997b). What do children fear most often? Journal of Behavior Therapy and Experimental Psychiatry. 28(4), 263-267.

https://doi.org/10.1016/S0005-7916(97)00024-4 
Muris, P., Merckelbach, H., Gadet, B., \& Moulaert, V. (2000). Fears, worries, and scary dreams in 4- to 12-year-old children: Their content, developmental pattern, and origins. Journal of Clinical Child Psychology, 29(1), 43-52. https://doi.org/10.1207/S15374424jccp2901_5

Muris, P., \& van Zwol L., \& Mayer, B. (2010). Mom told me scary things about this animal: Parents installing fear beliefs in their children via the verbal information pathway. Behaviour Research and Therapy, 48(4), 341-346. https://doi.org/10.1016/j.brat.2009.12.001

Nakonečný, M. (2012). Emoce. Praha: Triton.

Neff, J. A. E., \& Dale, J. C. (1996). Worries of school-aged children. Journal for Specialists in Pediatric Nursing, 1(1), 27-32. https://doi.org/10.1111/j.1744-6155.1996.tb00052.x

Ollendick, T. H. (1983). Reliability and validity of the revised fear survey schedule for children (FSSC-R). Behaviour Research and Therapy, 21(6), 685-692.

https://doi.org/10.1016/0005-7967(83)90087-6

Salcuni, S., Dazzi, C., Mannarini, S., Di Riso, D., \& Delvechino, E. (2015). Parents' perception of children's fear: from FSSC-IT to FSSCPP. Frontiers in Psychology, 1(6), 1-10. https://doi.org/10.3389/fpsyg.2015.01199

Sayfan, L., \& Lagattuta, K. H. (2009). Scaring the monster away: What children know about managing fears of real and imaginary creatures. Child Development, 80(6), 1756-1774. https://doi.org/10.1111/j.1467-8624.2009.01366.x

Scherer, M. W., \& Nakamura, C. Y. (1968). A fear survey schedule for children (FSS-FC): A factor analytic comparison with manifest anxiety (CMAS). Behaviour Research and Therapy, 6(2), 173-182. https://doi.org/10.1016/0005-7967(68)90004-1

Sharon, T., \& Woolley, J. D. (2004). Do monsters dream? Young children's understanding of the fantasy/reality distinction. British Journal of Developmental Psychology, 22, 293-310. https://doi.org/10.1348/026151004323044627

Stuchlíková, I. (2007). Základy psychologie emocí. Praha: Portál.

Tillich, P. (2004). Odvaha být. Brno: Centrum pro studium demokracie a kultury.

Volková, A., \& Dušková, P. (2015). Specific fears in emerging adulthood among Czech undergraduate students. Procedia - Social and Behavioral Sciences, 171, 487-493. https://doi.org/10.1016/j.sbspro.2015.01.151

Vymětal, J. (2004). Úzkost a strach u dětí. Praha: Portál.

Zábranská, N. (2006). Úzkost a strach u dětí a mládeže. Diplomová práce. Brno: Masarykova univerzita v Brně, Filozofická fakulta. https://theses.cz/id/w6ts16/ 


\section{Př́loha 1}

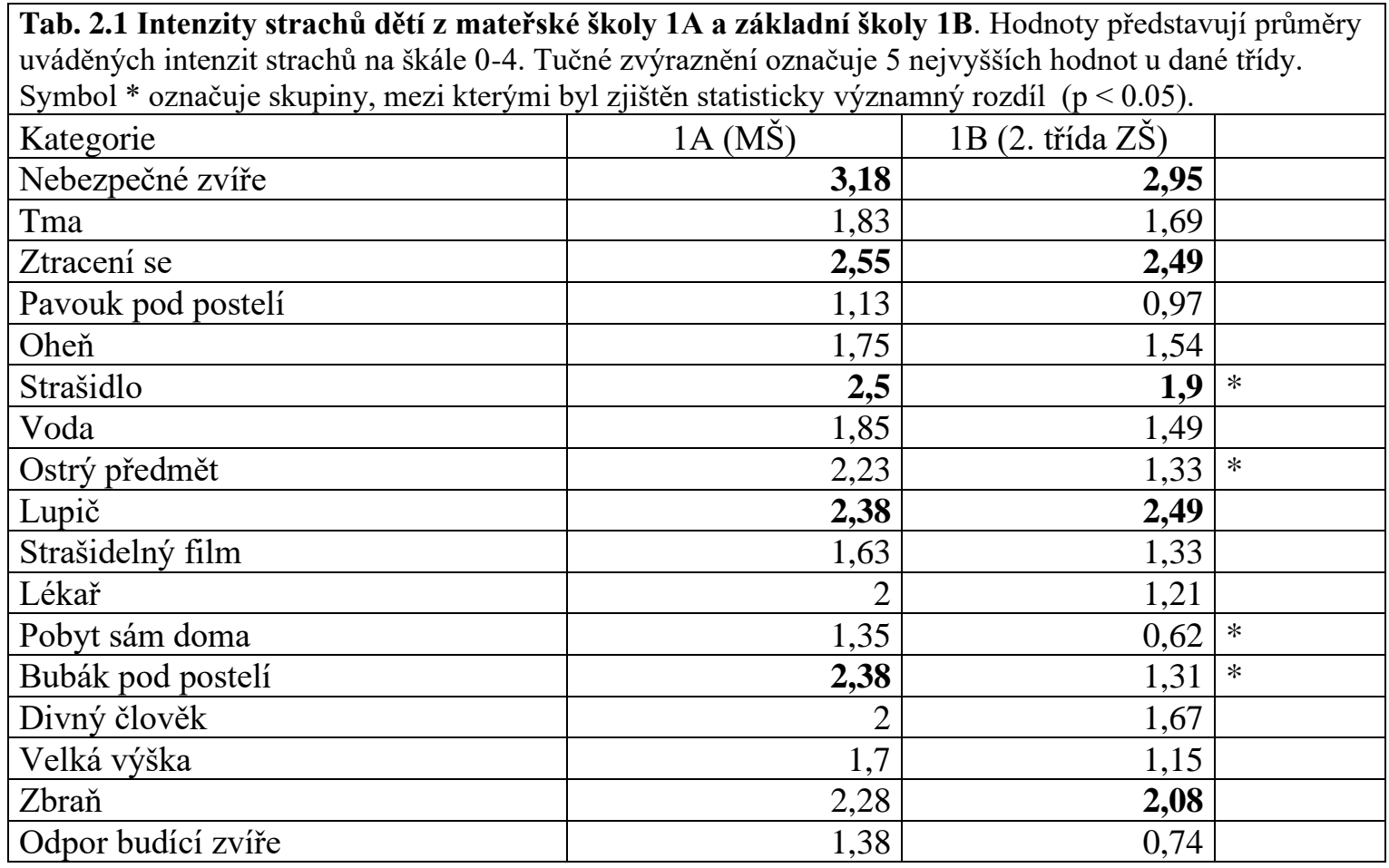

Tab. 2.2 Intenzity strachů dětí z 2. tříd 2A a 4. tříd 2B základní školy. Hodnoty představují průměry uváděných intenzit strachů na škále 0-4. Tučné zvýraznění označuje 5 nejvyšších hodnot u dané třídy. Symbol * označuje skupiny, mezi kterými byl zjištěn statisticky významný rozdíl $(\mathrm{p}<0.05)$.

\begin{tabular}{|l|r|r|l|}
\hline & 2A & 2B & \\
\hline Nebezpečné zviře & $\mathbf{2 , 8 8}$ & $\mathbf{2 , 4 7}$ & \\
\hline Tma & 1,21 & 1,19 & \\
\hline Ztracení se & $\mathbf{2 , 6 1}$ & $\mathbf{2 , 4 2}$ & \\
\hline Pavouk pod postelí & 1,24 & 0,89 & \\
\hline Oheň & 1,64 & 1,50 & \\
\hline Strašidlo & $\mathbf{2 , 3 9}$ & $\mathbf{1 , 8 3}$ & \\
\hline Voda & 1,36 & 1,22 & \\
\hline Ostrý předmět & 2,27 & 1,03 & $*$ \\
\hline Lupič & $\mathbf{2 , 6 4}$ & $\mathbf{2 , 4 7}$ & \\
\hline Strašidelný film & 1,36 & 1,64 & \\
\hline Lékař & 1,06 & 0,97 & \\
\hline Sám doma & 1,00 & 0,31 & $*$ \\
\hline Bubák pod postelí & 1,97 & 1,61 & \\
\hline Divný člověk & 1,70 & 1,75 & \\
\hline Velká výška & 1,61 & 1,22 & \\
\hline Zbraň & $\mathbf{2 , 6 7}$ & $\mathbf{1 , 8 6}$ & $*$ \\
\hline Odpor budící zvíře & 1,15 & 0,92 & \\
\hline Bouřka & 0,94 & 0,53 & \\
\hline
\end{tabular}


Tab. 2.3 Intenzity strachů u skupin 1dívky a 1chlapci. Hodnoty představují průměry uváděných intenzit strachů na škále 0-4. Tučné zvýraznění označuje 5 nejvyšších hodnot u dané třídy. Symbol * označuje skupiny, mezi kterými byl zjištěn statisticky významný rozdíl $(\mathrm{p}<0.05)$.

Kategorie

Nebezpečné zvíře

Tma

Ztracení se

Pavouk pod postelí

Oheň

Strašidlo

Voda

Ostrý předmět

Lupič

Strašidelný film

Lékař

Sám doma

Bubák pod postelí

Divný člověk

Velká výška

Zbraň

Odpor budící zvirire

\begin{tabular}{|r|l|l|}
\hline 1 dívky & 1chlapci & \\
\hline $\mathbf{3 , 3}$ & $\mathbf{2 , 8 2}$ & $*$ \\
\hline 1,67 & $\mathbf{1 , 8 5}$ & \\
\hline $\mathbf{2 , 6}$ & $\mathbf{2 , 4 4}$ & \\
\hline 1,38 & 0,72 & $*$ \\
\hline 1,98 & 1,31 & \\
\hline $\mathbf{2 , 1 5}$ & $\mathbf{2 , 2 6}$ & \\
\hline 1,78 & 1,56 & \\
\hline 2,13 & 1,44 & $*$ \\
\hline $\mathbf{2 , 8 3}$ & $\mathbf{2 , 0 3}$ & $*$ \\
\hline 1,73 & 1,23 & \\
\hline 1,7 & 1,51 & \\
\hline 1,1 & 0,87 & \\
\hline 2 & 1,69 & \\
\hline 1,9 & 1,77 & \\
\hline 1,68 & 1,18 & \\
\hline $\mathbf{2 , 6 5}$ & 1,69 & $*$ \\
\hline 1,15 & 0,97 & \\
\hline
\end{tabular}

Tab. 2.4 Intenzity strachů u skupin 2dívky a 2chlapci. Hodnoty představují průměry uváděných intenzit strachů na škále 0-4. Tučné zvýraznění označuje 5 nejvyšších hodnot u dané třídy. Symbol * označuje skupiny, mezi kterými byl zjištěn statisticky významný rozdíl $(\mathrm{p}<0.05)$.

\begin{tabular}{|l|r|r|l|}
\hline & 1 dívky & 2chlapci & \\
\hline Nebezpečné zvíře & $\mathbf{2 , 7 2}$ & $\mathbf{2 , 6 1}$ & \\
\hline Tma & 1,14 & 1,27 & \\
\hline Ztracení se & $\mathbf{2 , 6 7}$ & $\mathbf{2 , 3 3}$ & \\
\hline Pavouk pod postelí & 1,22 & 0,88 & \\
\hline Oheň & 1,67 & 1,45 & \\
\hline Strašidlo & $\mathbf{2 , 2 2}$ & $\mathbf{1 , 9 7}$ & \\
\hline Voda & 1,47 & 1,09 & \\
\hline Ostrý předmět & 1,89 & 1,33 & \\
\hline Lupič & $\mathbf{2 , 9 7}$ & $\mathbf{2 , 0 9}$ & $*$ \\
\hline Strašidelný film & 1,61 & 1,39 & \\
\hline Lékař & 0,72 & 1,33 & $*$ \\
\hline Sám doma & 0,72 & 0,55 & \\
\hline Bubák pod postelí & 1,92 & $\mathbf{1 , 6 4}$ & \\
\hline Divný člověk & 1,81 & $\mathbf{1 , 6 4}$ & \\
\hline Velká výška & 1,47 & 1,33 & \\
\hline Zbraň & $\mathbf{2 , 8 1}$ & $\mathbf{1 , 6 4}$ & $*$ \\
\hline Odpor budící zvíŕe & 1,22 & 0,82 & \\
\hline Bouřka & 0,83 & 0,61 & \\
\hline
\end{tabular}


Tab. 2.5 Intenzity strachů dětí u skupin 1AB a 2AB. Hodnoty představují průměry uváděných intenzit strachů na škále $0-4$. Tučné zvýraznění označuje 5 nejvyšších hodnot u dané tř́́dy. Symbol * označuje skupiny, mezi kterými byl zjištěn statisticky významný rozdíl $(\mathrm{p}<0.05)$.

\begin{tabular}{|l|r|r|l|}
\hline & 1AB & 2AB & \\
\hline Nebezpečné zvíře & $\mathbf{3 , 0 6}$ & $\mathbf{2 , 6 7}$ & $*$ \\
\hline Tma & 1,76 & 1,20 & $*$ \\
\hline Ztracení se & $\mathbf{2 , 5 2}$ & $\mathbf{2 , 5 1}$ & \\
\hline Pavouk pod postelí & 1,05 & 1,06 & \\
\hline Oheň & 1,65 & 1,57 & \\
\hline Strašidlo & $\mathbf{2 , 2}$ & $\mathbf{2 , 1 0}$ & \\
\hline Voda & 1,67 & 1,29 & \\
\hline Ostrý předmět & 1,78 & 1,62 & \\
\hline Lupič & $\mathbf{2 , 4 3}$ & $\mathbf{2 , 5 5}$ & \\
\hline Strašidelný film & 1,48 & 1,51 & \\
\hline Lékař & 1,61 & 1,01 & $*$ \\
\hline Sám doma & 0,99 & 0,64 & $*$ \\
\hline Bubák pod postelí & 1,85 & 1,78 & \\
\hline Divný člověk & 1,84 & 1,72 & \\
\hline Velká výška & 1,43 & 1,41 & \\
\hline Zbraň & $\mathbf{2 , 1 8}$ & $\mathbf{2 , 2 5}$ & \\
\hline Odpor budící zvíre & 1,06 & 1,03 & \\
\hline Bouřka & & 0,72 & \\
\hline
\end{tabular}


Graf 1.1 Znázornění průměrných hodnot intenzit strachů u skupin v závislosti na věku

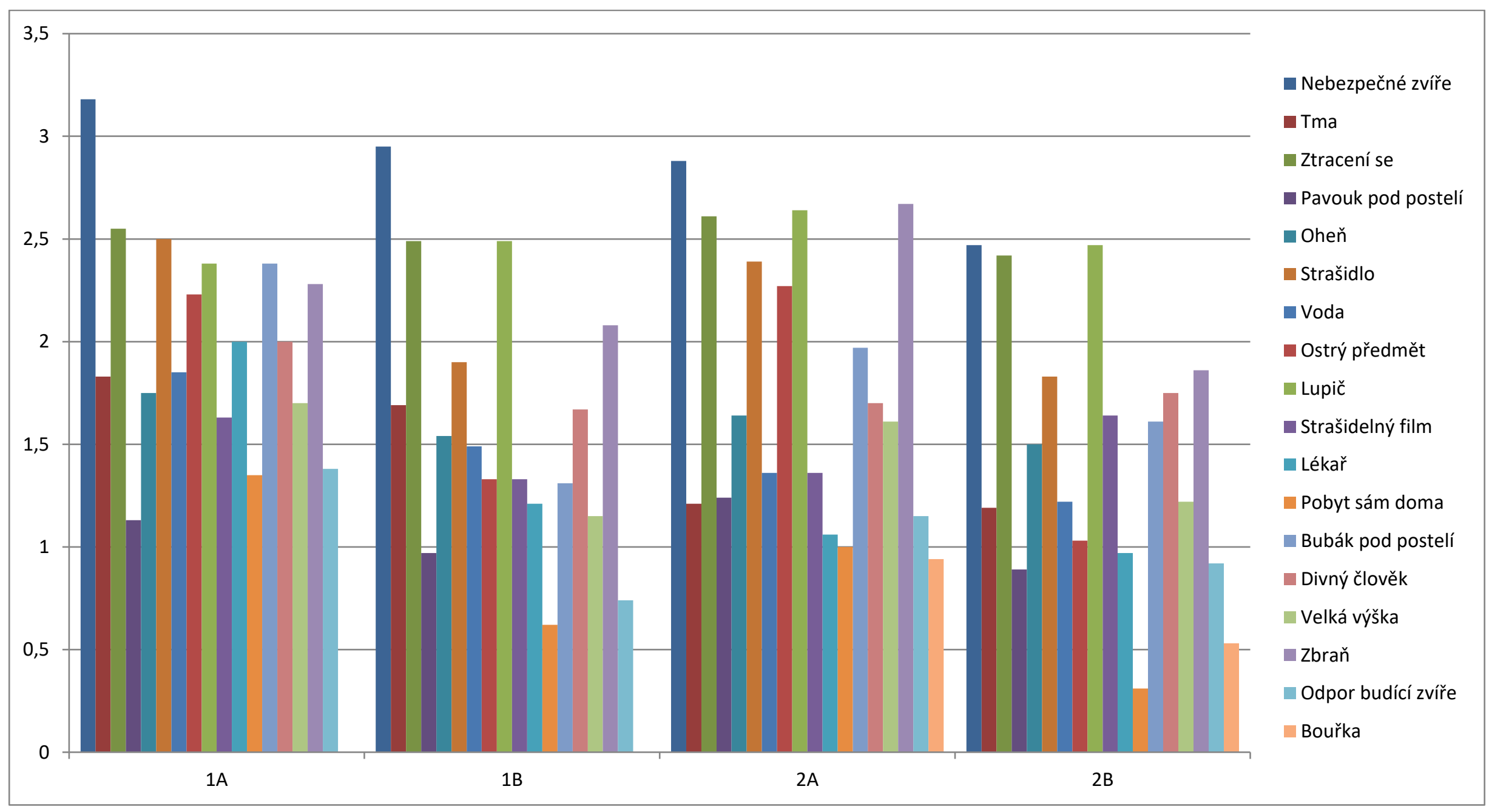


Graf 1.2 Znázornění průměrných hodnot intenzit strachů u skupin v závislosti na pohlaví

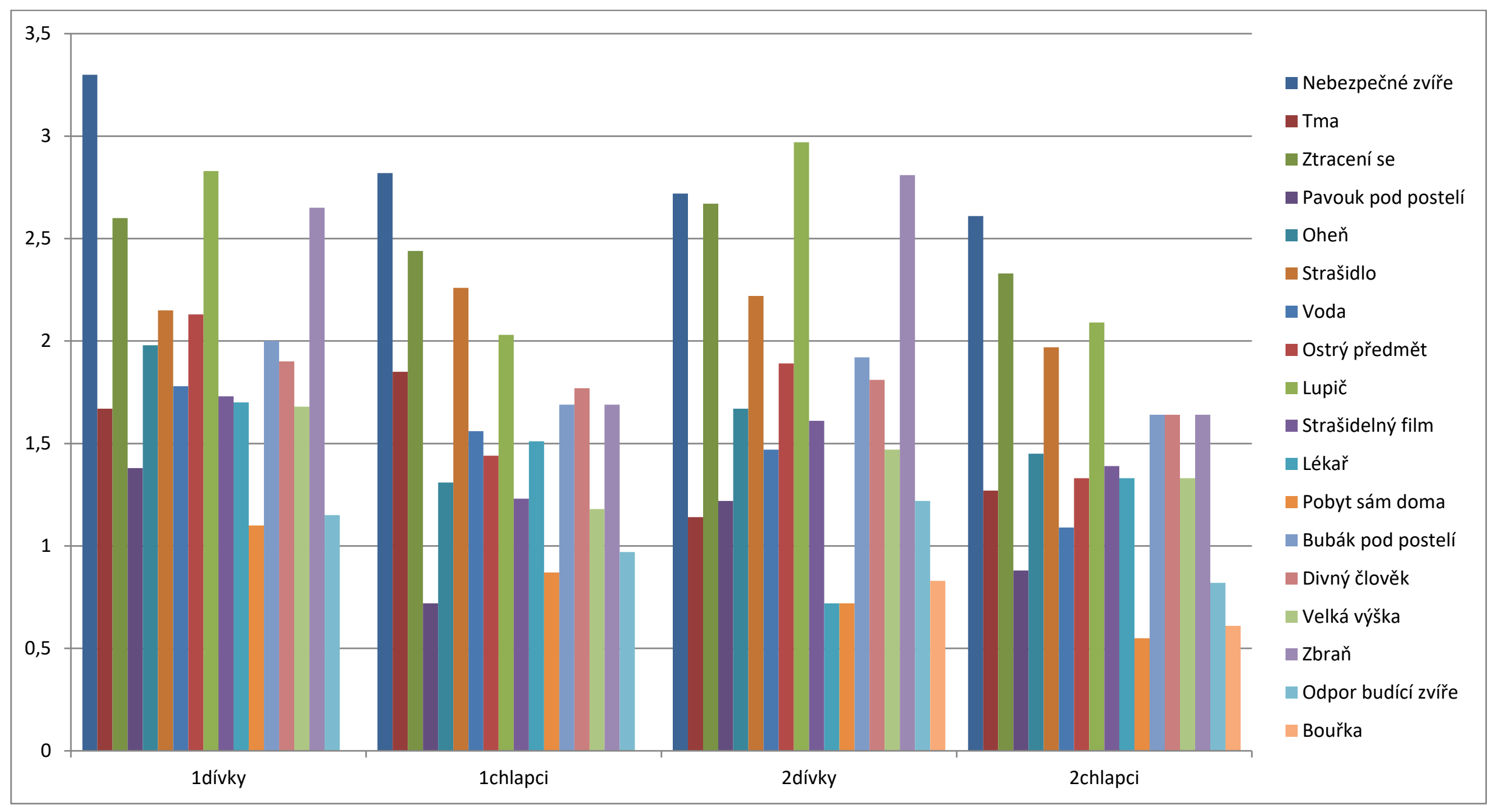


Graf 1.3 Znázornění průměrných hodnot intenzit strachů u dvou souhrnných skupin výzkumu (před a po 2 letech)

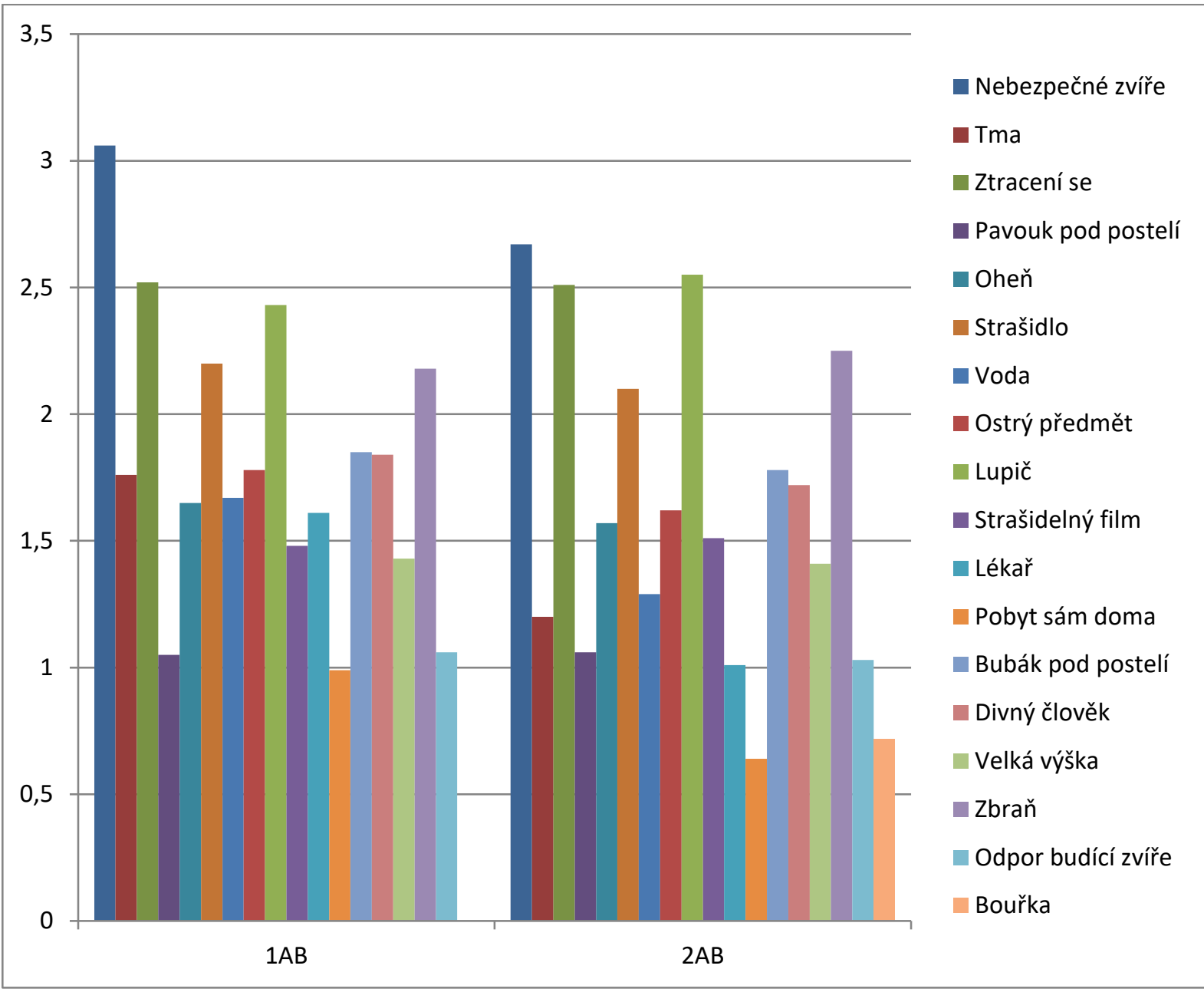


Graf 2.1 Nejintenzivnější strachy u skupin v závislosti a věku (od nejvyšších po nejnižší)

\begin{tabular}{|c|c|c|c|}
\hline $\begin{array}{c}\text { Nebezpečné } \\
\text { zviř́e }\end{array}$ & $\begin{array}{l}\text { Nebezpečné } \\
\text { zviríe }\end{array}$ & $\begin{array}{l}\text { Nebezpečné } \\
\text { zviŕ̌e }\end{array}$ & $\begin{array}{l}\text { Nebezpečné } \\
\text { zviŕ̌e }\end{array}$ \\
\hline Ztracení se & Ztracení se & Zbraň & Lupič \\
\hline Strašidlo & Lupič & Lupič & tracení se \\
\hline Lupič & Zbraň & tracení se & Zbraň \\
\hline $\begin{array}{l}\text { Bubák } \\
\text { pod } \\
\text { postelí }\end{array}$ & Strašidlo & Strašidlo & Strašidlo \\
\hline $1 \mathrm{~A}$ & 1B & $2 \mathrm{~A}$ & $2 \mathrm{~B}$ \\
\hline
\end{tabular}

Graf 2.2 Nejintenzivnější strachy u skupin v závislosti na pohlaví (od nejvy̌̌ších po nejnižší); * Páté místo u skupiny 2 chlapci zastupují se stejnými průměrnými hodnotami kategorie bubák pod postelí, divný člověk, zbraň

\begin{tabular}{|c|c|c|c|}
\hline $\begin{array}{c}\text { Nebezpečné } \\
\text { zviř́e }\end{array}$ & $\begin{array}{l}\text { Nebezpečné } \\
\text { zviř́e }\end{array}$ & Lupič & $\begin{array}{l}\text { Nebezpečné } \\
\text { zviř́e }\end{array}$ \\
\hline Lupič & Ztracení se & Zbraň & Ztracení s \\
\hline Zbraň & Strašidlo & $\begin{array}{l}\text { Nebezpečné } \\
\text { zviŕe }\end{array}$ & Lupič \\
\hline ztracení se & Lupič & Ztracení se & Strašidlo \\
\hline Strašidlo & Tma & Strašidlo & * \\
\hline 1dívky & 1chlapci & 2dívky & 2chlapci \\
\hline
\end{tabular}




\section{Př́loha 2}

Obr. 1 Obrázky obličejů využité ke škálování strachů
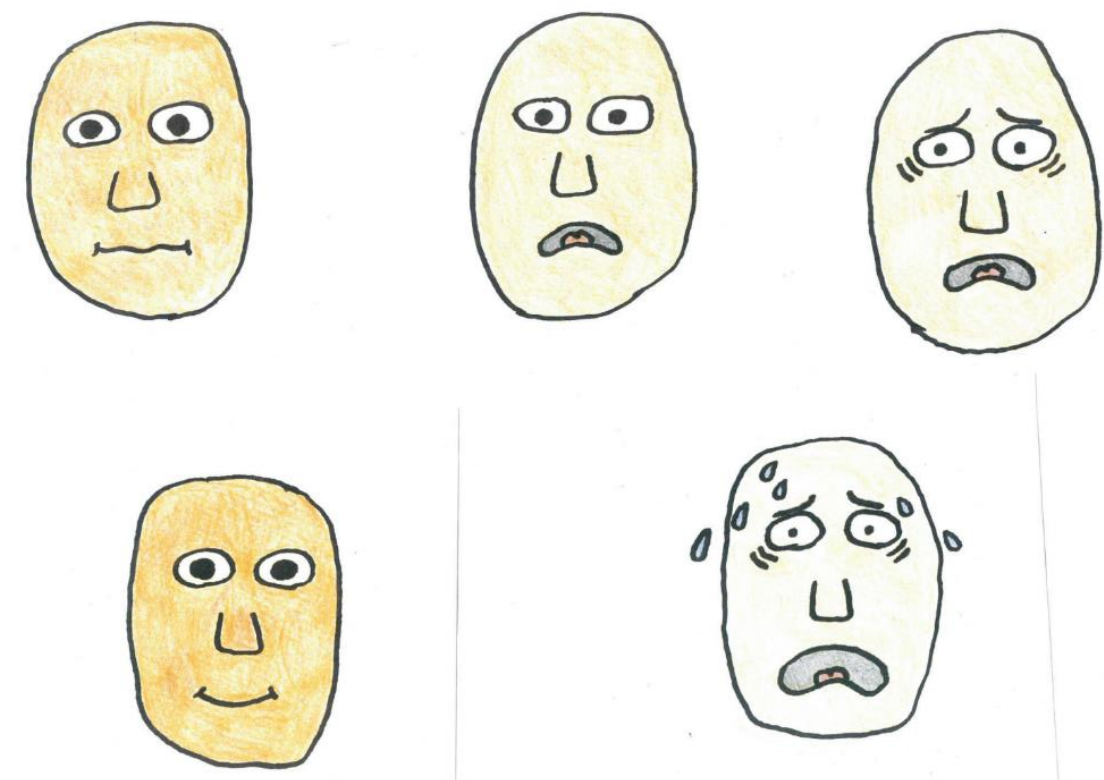

Obr. 2 Ukázka karet reprezentujících strašidelné objekty (oheň, pavouk pod postelí, voda, strašidlo)
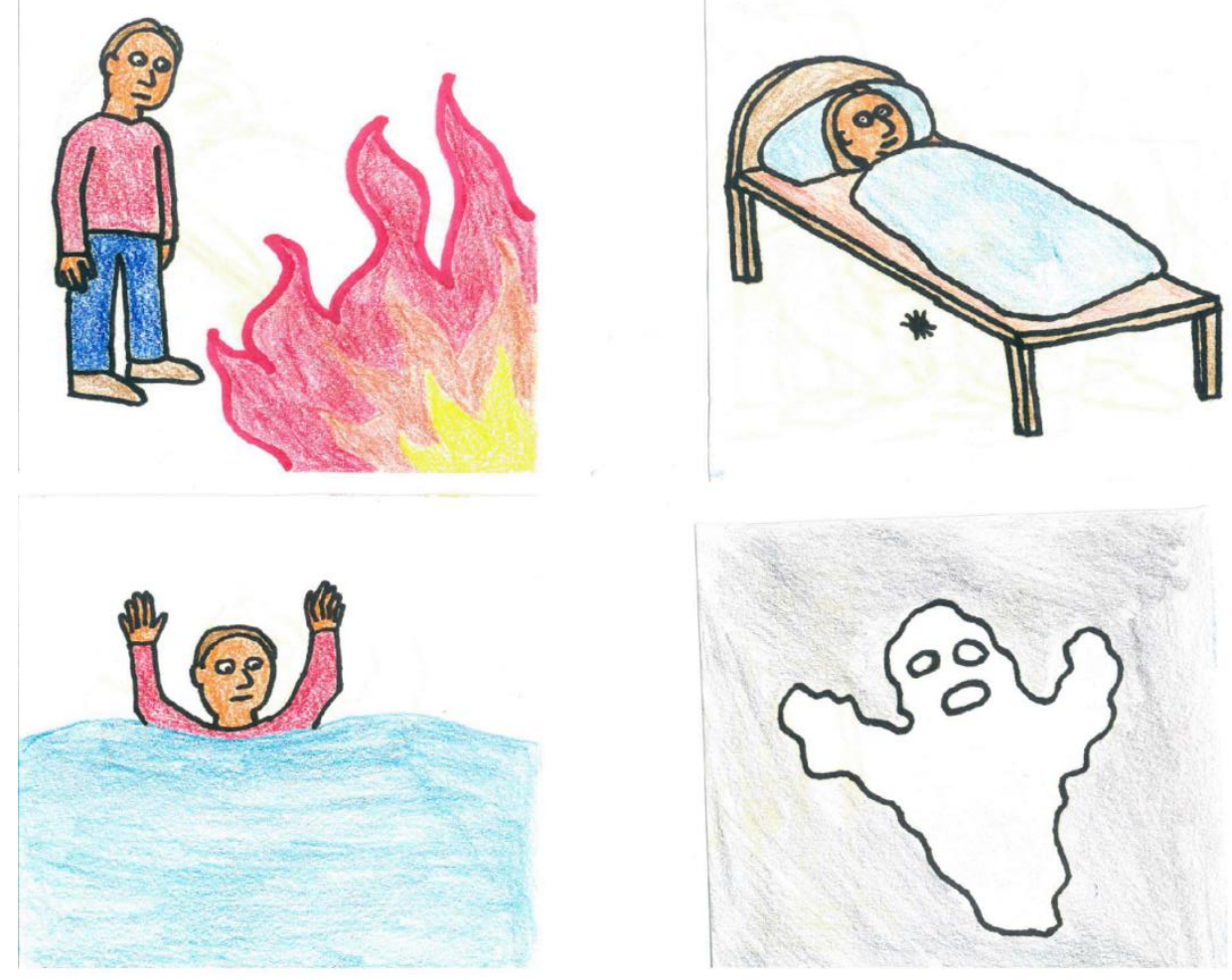


\section{Údaje o autorech}

Mgr. Martin Brummer je absolventem psychologie na PedF UK. Je studentem doktorského oboru Pedagogická psychologie na PedF UK a pracuje jako psycholog v Pedagogickopsychologické poradně Středočeského kraje.

\section{Kontaktní údaje:}

Adresa: Katedra psychologie PedF UK, Myslíkova 7, Praha 1

E-mail: brummer@pppsk.cz

PhDr. et Mgr. Hana Valentová vystudovala psychologii a speciální pedagogiku na PedF UK (2005) a psychologii na FF MU v Brně (2010), je studentkou doktorského studia Pedagogické psychologie. Od roku 2013 působí na Katedře psychologie PedF na pozici odborného asistenta.

Kontaktní údaje:

Adresa: Katedra psychologie PedF UK, Myslíkova 7, Praha 1

E-mail: hana.valentova@pedf.cuni.cz

Brummer, M., \& Valentová, H. (2019). Zloději nebo strašidla: čeho se bojí české děti?

E-psychologie, 13(3), 1-24. https://doi.org./10.29364/epsy.348 